\title{
First chromosome analysis of Thai pufferfish Pao cochinchinensis (Steindachner, 1866)
}

\author{
MANACHAYA PISSAPARN ${ }^{1}$, SUMALEE PHIMPHAN ${ }^{2}$, PATCHARAPORN CHAIYASAN ${ }^{1}$, \\ ALONGKLOD TANOAMTONG ${ }^{1}$, THOMAS LIEHR ${ }^{3}$, CHATMONGKON SUWANNAPOOM $^{4}$, \\ MONTRI REUNGSING ${ }^{5}$, WEERAYUTH SUPIWONG ${ }^{6,9}$ \\ ${ }^{1}$ Department of Biology, Faculty of Science, Khon Kaen University. Muang, Khon Kaen 40002, Thailand \\ ${ }^{2}$ Biology Program, Faculty of Science and Technology, Phetchabun Rajabhat University. Phetchabun 67000, Thailand \\ ${ }^{3}$ Jena University Hospital, Friedrich Schiller University, Institute of Human Genetics. Am Klinikum 1, D-07747 Jena, Germany \\ ${ }^{4}$ Department of Fishery, School of Agriculture and Natural Resources, University of Phayao. Muang, Phayao 56000, Thailand \\ ${ }^{5}$ Department of Biotechnology, Faculty of Science and Technology, Rajamangala University of Technology Tawan-ok. Sri Racha, Chon Buri 20110 , \\ Thailand \\ ${ }^{6}$ Faculty of Interdisciplinary Studies, Khon Kaen University, Nong Khai Campus. Muang, Nong Khai 43000, Thailand. \\ Tel.: +66-910600425, Fax.: +66-42-415699, `email: supiwong@ hotmail.com
}

Manuscript received: 13 May 2020. Revision accepted: 26 August 2020.

\begin{abstract}
Pissaparn M, Phimphan S, Chaiyasan P, Tanoamtong A, Liehr T, Suwannapoom C, Reungsing M, Supiwong W. 2020. First chromosome analysis of Thai pufferfish Pao cochinchinensis (Steindachner, 1866). Biodiversitas 21: 4309-4316. Here first analysis of chromosomes and nucleolar organizer region (NOR) pattern in pufferfish Pao cochinchinensis (Steindachner, 1866) was undertaken. Chromosomal preparations were obtained from kidney of $P$. cochinchinensis from Chi River basin in Thailand. Chromosomal characteristics were analyzed by Giemsa staining, Ag-NOR banding as well as fluorescence in situ hybridization (FISH) using microsatellites $\mathrm{d}(\mathrm{CA})_{15}$ and $\mathrm{d}(\mathrm{CGG})_{10}$ probes. $P$. cochinchinensis had $2 n=40$ with the fundamental number $(\mathrm{NF}) 74$, both in male and female. The karyotype exhibited 12 metacentric (m), 10 submetacentric (sm), 12 acrocentric (a) and 6 telocentric (t) chromosomes. No differentiated heteromorphic sex chromosomes were observed. NORs were located on short arms adjacent to telomere of the metacentric chromosome pair 4 , which coincide with signals of $\mathrm{d}(\mathrm{CGG})_{10}$ probe. FISH with $\mathrm{d}(\mathrm{CGG})_{10}$ sequences were also displayed at the telomeres of most other chromosomes, whereas d(CA) 15 repeats highly accumulated throughout almost all entire chromosomes except for centromeric regions. The results of conventional Giemsa staining presented the differentiation even the same genus. The localization of NORs on one pair of chromosomes only is a common characteristic found in many fish groups as well as other vertebrates. Mapping of two distinct microsatellites demonstrated the remarkable chromosomal diversification that characterizes evolution in the genus Pao. Both, conventional and molecular cytogenetics are excellent tools to study, and better understand chromosomal evolution, as well as to uncover biodiversity among fishes.
\end{abstract}

Keywords: Chromosome, FISH, karyotype, Nucleolar Organizer Region, Pao cochinchinensis

Abbreviations: 2n: diploid chromosome number; NF: fundamental number or number of chromosome arm; FISH: fluorescence in situ hybridization technique; NOR: nucleolar organizer region; m: metacentric chromosome; sm: submetacentric chromosome; a: acrocentric chromosome; t: telocentric chromosome

\section{INTRODUCTION}

Up to the present, there are approximately 191 valid species of pufferfish in the list of the catalog of fishes (Eschmeyer et al. 2017). Pao Kottelat, 2013 is a genus of the Tetraodontidae family and is the most common freshwater pufferfish, except for P. leiurus (Bleeker, 1850) which also occurs in brackish water (Kottelat 2013). Pao species are found in Southeast Asia and have been placed in the Tetraodon since 2013 )Kottelat 2013). Up to date, there are 15 recognized species in the genus Pao (Eschmeyer et al. 2017). P. cochinchinensis is part of the genus $P a o$, which contains four other species, i.e. $P$. cambodgiensis (Chabanaud, 1923), P. leirus, P. turgidus (Kottelat 2000) and P. hilgendorfi (Popta, 1905). As they all hail from the same geographical area and share very similar physical characteristics, they are hard to distinguish from each other. Still, $P$. cochinchinensis has a clear red spot situated towards the rear of the fish, enabling its indubitable identification (Figure 1). All Pao species are ambush predators in nature (Kottelat 2013). Concerning their commercial value, pufferfishes are often less expensive than other fishes on the local markets, as they contain inconsistent levels of toxins, depending on fish and season.

Pufferfishes have the smallest chromosomes so far described in vertebrates, hampering high-resolution cytogenetic analyses, so far (Myers 2008). Only 25 species in Tetraodontidae with one species of the genus Poa were cytogenetic analyzed (Arai 2011; Table 1) so far. The $2 n$ range from 28 in Canthigaster coronata (Vaillant \& Sauvage, 1875) (Arai 2011) to 46 chromosomes in the genus Sphoeroides anonymous, 1798 (Brum et al. 1995, Brum 2000, Sá-Gabriel and Molina 2005, Alves et al. 
2008). Shape, size, and number of chromosomes of each species are always fixed, so knowledge about the karyotypes can be used for studies in taxonomy, diversity, kinship, and evolution, even though in certain circumstances also variations have been reported (Hartati et al. 2017). To identify intra- and inter-specific variants karyotyping combined with molecular cytogenetic analyses are the methods best suited here. This kind of approach has played an important role in the precise characterization of structure of genomes (Cioffi and Bertollo 2012), and checking the ploidy status in Acipenser mikadoi (Zhou et al. 2013). Recently, molecular cytogenetic studies using fluorescence in situ hybridization (FISH) for mapping repetitive DNA sequences have provided important contributions to the characterization of biodiversity and evolution of divergent fish groups (Cioffi et al. 2018).
However, this kind of study is scarcely applied in Thai freshwater fish. Exceptions are studies in Bagrid catfishes (Supiwong et al. 2013, 2014a,b), Channids (Cioffi et al. 2015), three Clarias species (Maneechot et al. 2016), Toxotes chatareus (Hamilton, 1822) (Supiwong et al. 2017), two cyprinid fishes (Saenjundaeng et al. 2018), Asian swamp eel, Monopterus albus (Zuiew, 1793) (Supiwong et al. 2019) and silulid catfishes (Ditcharoen et al. 2019). The present study is the first report on chromosomal characteristics in $P$. cochinchinensis using conventional staining, Ag-NOR banding, and FISH technique, being the basis for further study by advanced genetics and for future comparative approaches concerning systematics and evolutionary relationships of buffer-fishes.

Table 1. Yet available cytogenetic reports on the family Tetraodontidae

\begin{tabular}{|c|c|c|c|c|c|c|}
\hline Species & $2 n$ & NF & Karyotype & NORs & Locality & Reference \\
\hline Arothron hispidus & 42 & - & - & - & India & Arai (2011) \\
\hline A. immaculatus & 42 & 68 & $12 \mathrm{~m}+14 \mathrm{sm}+16 \mathrm{st} / \mathrm{a}$ & - & India & Arai (2011) \\
\hline A. manilensis & 42 & 72 & $14 m+16 s m+12 s t$ & - & Japan & Arai (2011) \\
\hline A. meleagris & 38 & - & - & - & Japan & Arai (2011) \\
\hline A. reticularis & 42 & 68 & $12 \mathrm{~m}+14 \mathrm{sm}+16 \mathrm{st} / \mathrm{a}$ & - & India & Arai (2011) \\
\hline Canthigaster coronata & 28 & 36 & $6 m+2 s m+20 s t / a$ & - & Japan & Arai (2011) \\
\hline C. rivulate & 34 & 44 & $4 m+6 s m+10 s t+14 a$ & - & Japan & Arai (2011) \\
\hline C. patoca & 40 & 70 & $14 \mathrm{~m}+16 \mathrm{sm}+10 \mathrm{st} / \mathrm{a}$ & - & Japan & Arai (2011) \\
\hline \multirow[t]{2}{*}{ Dichotomyctere fluviatilis } & 42 & 64 & $2 m+4 s m+2 s t+34 a$ & - & India & Arai (2011) \\
\hline & 42 & 48 & $2 m+4 s m+2 s t+34 a$ & - & S.Asia & Arai (2011) \\
\hline D. nigroviridis & 42 & 62 & $20 \mathrm{~m} / \mathrm{sm}+22 \mathrm{st}$ & - & S.Asia & Hardie and Hebert (2003) \\
\hline Legocenphalus inermis & 44 & 46 & $2 \mathrm{~m}+42 \mathrm{a}$ & - & India & Arai (2011) \\
\hline L. laevigatus & 46 & - & - & - & Brazil & Sá-Gabriel and Molina (2005) \\
\hline L. lunaris & 44 & 68 & $10 \mathrm{~m}+14 \mathrm{sm}+20 \mathrm{st} / \mathrm{a}$ & - & India & Hardie and Hebert (2003) \\
\hline *Pao cochinchinesis & 40 & 74 & $12 m+10 s m+12 a+6 t$ & 2 & Thailand & *Present study \\
\hline P. palemnangensis & 42 & - & - & - & S.Asia & Arai (2011) \\
\hline Sphoeroides greeleyi & 46 & 70 & $24 \mathrm{~m} / \mathrm{sm}+22 \mathrm{st} / \mathrm{a}$ & 2 & Brazil & Brum et al. (1995) \\
\hline \multirow[t]{2}{*}{ S. spengleri } & 46 & 64 & $18 \mathrm{~m} / \mathrm{sm}+28 \mathrm{st} / \mathrm{a}$ & - & Brazil & Brum et al. (1995) \\
\hline & 46 & 66 & $20 \mathrm{~m} / \mathrm{sm}+26 \mathrm{st} / \mathrm{a}$ & - & Brazil & Alves et al. (2008) \\
\hline S. testudineus & 46 & 68 & $18 m+4 s m+6 s t+18 a$ & 2 & Brazil & Sá-Gabriel and Molina (2005) \\
\hline S. tyleri & 46 & 60 & $14 \mathrm{~m} / \mathrm{sm}+32 \mathrm{st} / \mathrm{a}$ & - & Brazil & Brum (2000) \\
\hline Takifugu chrysops & 44 & 64 & $6 m+14 s m+24 s t / a$ & - & Japan & Arai (2011) \\
\hline \multirow{2}{*}{ T. niphobles } & 44 & 64 & $24 \mathrm{~m} / \mathrm{sm}+24 \mathrm{st} / \mathrm{a}$ & - & Japan & Arai (2011) \\
\hline & 44 & 64 & $4 m+16 s m+24 s t / a$ & - & Japan & Arai (2011) \\
\hline \multirow[t]{2}{*}{ T. pardalis } & 44 & - & - & - & Japan & Arai (2011) \\
\hline & 44 & 66 & $6 m+16 s m+22 s t / a$ & - & Japan & Arai (2011) \\
\hline \multirow[t]{3}{*}{ T. poecilonotus } & 44 & 66 & $12 \mathrm{~m}+10 \mathrm{sm}+22 \mathrm{st} / \mathrm{a}$ & - & Japan & Arai (2011) \\
\hline & 44 & 66 & - & - & Japan & Arai (2011) \\
\hline & 44 & 66 & $12 m+8 s m+24 a$ & - & China & Arai (2011) \\
\hline \multirow[t]{3}{*}{ T. rubripes } & 44 & 66 & $10 \mathrm{~m}+12 \mathrm{sm}+22 \mathrm{st} / \mathrm{a}$ & - & Japan & Arai (2011) \\
\hline & 44 & 64 & $20 \mathrm{~m} / \mathrm{sm}+24 \mathrm{st} / \mathrm{a}$ & - & China & Arai (2011) \\
\hline & 44 & 62 & $12 m+6 s m+26 a$ & - & China & Arai (2011) \\
\hline T. vermicularis & 44 & 66 & $8 m+14 s m+22 s t / a$ & - & Japan & Arai (2011) \\
\hline T. xanthopterus & 44 & 66 & $8 m+14 s m+22 s t / a$ & - & Japan & Arai (2011) \\
\hline Tetraodon cutcutia & 42 & 70 & $16 \mathrm{~m}+12 \mathrm{sm}+4 \mathrm{st}+10 \mathrm{a}$ & - & India & Arai (2011) \\
\hline
\end{tabular}

Note: $2 n$ : diploid chromosome number, NF: fundamental number (number of chromosome arm), m: metacentric, sm: submetacentric, a: acrocentric, t: telocentric, NORs: nucleolar organizer regions, S.: Southeast, and -: not available 


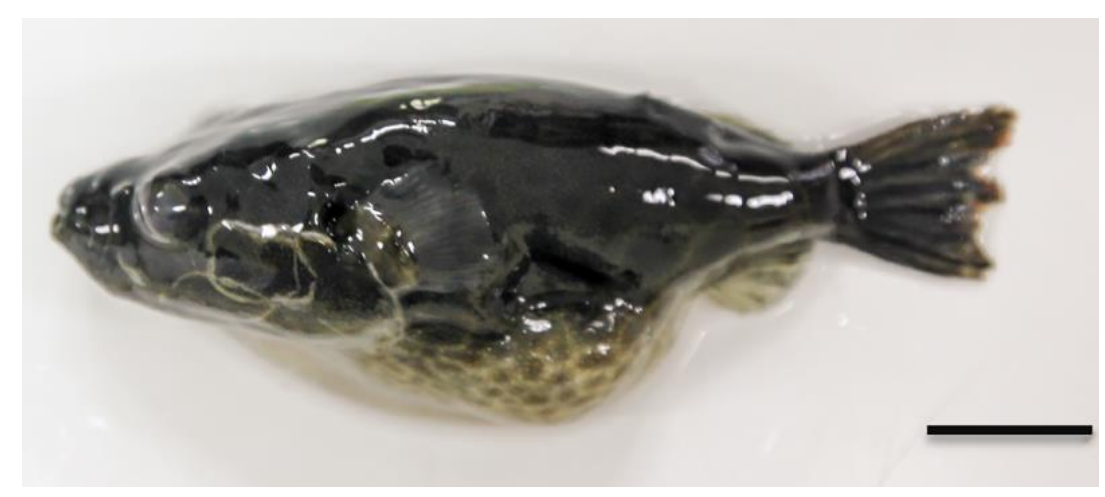

Figure 1. General morphological characteristics of pufferfish, Pao cochinchinensis. Bar $=2 \mathrm{~cm}$

\section{MATERIALS AND METHODS}

\section{Sample collection}

Four male and four female specimens of $P$. cochinchinensis were obtained from the Chi River, Roi-Et Province, Northeast of Thailand. The fishes were transferred to laboratory aquaria and kept under standard conditions for three days before the experiments.

\section{Chromosome preparation}

Chromosomes were prepared in vivo (Supiwong et al. 2012a, 2013b, Kasiroek et al. 2017) as follows. Colchicine solution $(0.05 \%, 1 \mathrm{ml} / 100 \mathrm{~g}$ body weight) was injected into the fish's intramuscular and/or its abdominal cavity and then left for $1 \mathrm{~h}$. The kidney tissues were cut into small pieces, and then squash mixed with $0.075 \mathrm{M} \mathrm{KCl}$. After discarding all large pieces of tissue, $8 \mathrm{ml}$ of cell sediments were transferred to a centrifuge tube and incubated for 25 $35 \mathrm{~min}$ at room temperature. The $\mathrm{KCl}$ was discarded from the supernatant after centrifugation at 1,200 rpm for $8 \mathrm{~min}$. Cells were fixed in fresh, cool fixative )3 methanol: 1 glacial acetic acid(.

\section{Chromosome staining}

Conventional staining by $20 \%$ Giemsa's solution for 30 min was carried out following Supiwong et al. (2012b, Getlekha et al. 2017) and Ag-NOR banding was conducted by adding 4 drops of $50 \%$ silver nitrate solution and 2 drops of $2 \%$ gelatin solution on slides with spread metaphases, respectively. The slides were then sealed with coverslips and incubated at $60^{\circ} \mathrm{C}$ for $5 \mathrm{~min}$. After that, slides were soaked in distilled water until the coverslips were separated. The slide was stained with $20 \%$ Giemsa's solution for $1 \mathrm{~min}$ (Sangpakdee et al. 2017, Chaiyasan et al. 2018).

\section{Chromosome characterization}

Chromosome counting was performed on mitotic metaphase cells under a light microscope. Twenty clearly observable and well-spread metaphase plates of male and female, each was selected and documented. The length of short chromosome arm (Ls) and long chromosome arm (Ll) were measured and calculated to the length of total chromosome (LT, LT=Ls+Ll). The relative length (RL), the centromeric index (CI), and standard deviation (S.D.) of RL and CI were estimated. The CI $(\mathrm{q} / \mathrm{p}+)$ (between 0.50 $0.59,0.60-0.69,0.70-0.89$, and $0.90-1.00$ are described as metacentric, submetacentric, acrocentric, and telocentric chromosomes, respectively. The fundamental number (number of chromosome arm, NF) was obtained by assigning a value of two to metacentric, submetacentric and acrocentric chromosomes and one to telocentric chromosome. All parameters were used in karyotyping and idiogramming (Tanomtong et al. 2014, Chooseangjaew et al. 2017).

\section{FISH technique}

The use of microsatellites $\mathrm{d}(\mathrm{CA}) 15$, and $\mathrm{d}(\mathrm{CGG})_{10}$ probes described by Kubat et al. (2008) followed here with slight modifications. These sequences were directly labeled with $\mathrm{Cy} 3$ at $5^{\prime}$ terminal during synthesis by Sigma (St. Louis, MO, USA). FISH was performed under high stringency conditions on mitotic chromosome spreads (Cioffi et al. 2011). After denaturation of chromosomal DNA in $70 \%$ formamide/ $2 \times \mathrm{SSC}$ at $70{ }^{\circ} \mathrm{C}$, spreads were incubated in $2 \times \mathrm{SSC}$ for $4 \mathrm{~min}$ at $70{ }^{\circ} \mathrm{C}$. The hybridization mixture $(2 \mu \mathrm{L}$ probes and $8 \mu \mathrm{L}$ hybridization buffer) was dropped on the slides, and the hybridization was performed overnight at $37^{\circ} \mathrm{C}$ in a moist chamber containing $2 \times \mathrm{SSC}$. The post hybridization wash was carried out with $1 \times \mathrm{SSC}$ for $5 \mathrm{~min}$ at $65^{\circ} \mathrm{C}$. A final wash was performed at room temperature in $4 \times$ SSCT for 5 min (Supiwong et al. 2017 2019). Finally, the slides were counterstained with DAPI and mounted in an antifade solution (Vectashield from Vector laboratories), and analyzed in an epifluorescence microscope Olympus BX50 (Olympus Corporation, Ishikawa, Japan). 


\section{RESULTS AND DISCUSSION}

\section{Chromosome number, fundamental number, and karyotype of Pao cochinchinensis}

The chromosome number in $P$. cochinchinensis was $2 n=40$. The NF was 74 in both males and females (Figure 2A). There were four types of chromosomes in this species including metacentric, submetacentric, acrocentric, and telocentric chromosomes. Three sizes of chromosomes including large, medium, and small can be distinguished. The details of the autosome types and sizes are presented as follows: eight large metacentrics, six large submetacentric, four large acrocentrics, four medium metacentrics, four medium submetacentric, four medium acrocentric, four small acrocentric and six small telocentric chromosomes (Table 2). No differentiated heteromorphic sex chromosomes were observed. The karyotype formula for $P$. cochinchinensis could be deduced as:

$$
2 n \text { (diploid) } 40=\mathrm{L}^{\mathrm{m}}{ }_{8}+\mathrm{M}^{\mathrm{m}}{ }_{4}+\mathrm{L}^{\mathrm{sm}}{ }_{6}+\mathrm{M}^{\mathrm{sm}}{ }_{4}+\mathrm{L}^{\mathrm{a}}{ }_{4}+\mathrm{M}^{\mathrm{a}}{ }_{4}+\mathrm{S}_{4}^{\mathrm{a}}+\mathrm{S}_{6}^{\mathrm{t}}
$$

\section{Chromosome markers of $\boldsymbol{P}$. cochinchinensis}

The determination of chromosome marker for this species was firstly obtained by using the Ag-NOR banding technique. These regions can be detected by silver nitrate staining, if they are active during the interphase prior to mitosis since they specifically stain a set of acidic proteins related to ribosomal synthesis process; this technique actually reveals active NORs but cannot detect inactive rDNA associated to NORs (Supiwong et al. 2014a). The regions adjacent to the telomere of the short arms of the metacentric chromosome pair 4 exhibited active Ag-NOR signals (Figure 2B).

\section{Patterns of d(CA) 15 and d(CGG) 10 microsatellite repeats in Pao cochinchinensis}

The results of mapping of microsatellite repeats on the chromosomes of $P$. cochinchinensis showed that $\mathrm{d}(\mathrm{CGG})_{10}$ microsatellite repeat signals are highly accumulated at the telomeric regions of several chromosome pairs including the regions coincident with the NOR position (chromosome pair 4), and the interstitial positions of some other pairs (Figure 2.C. However, the patterns of $\mathrm{d}(\mathrm{CA})_{15}$ microsatellite repeats are more accumulated than those of $\mathrm{d}(\mathrm{CGG})_{10}$ microsatellite repeats. The $\mathrm{d}(\mathrm{CA})_{15}$ microsatellite repeats signals are observed on all chromosome pairs. These signals are distributed throughout the whole chromosomes except for centromeric regions of most chromosome pairs whereas, in some pairs, they were found on the whole chromosome (Figures 2.D).

\section{Idiograms of Pao cochinchinensis chromosomes}

In Figure 3 all previous results are summarized and idiograms of $P$. cochinchinensis are provided.

Table 2. Mean length of short arm chromosomes (Ls), length long arm chromosomes (Ll), length total arm chromosomes (LT), relative length (RL), centromeric index (CI) and standard deviation (SD) of CI, RL from 20 metaphases of Pao cochinchinesis, $2 n=40$.

\begin{tabular}{lcccccll}
\hline Pair & Ls & L & LT & $\mathbf{C I} \pm \mathbf{S D}$ & $\mathbf{R L} \pm$ SD & Size & Type \\
\hline 1 & 0.87 & 0.89 & 1.76 & $0.503 \pm 0.135$ & $0.081 \pm 0.016$ & Large & metacentric \\
2 & 0.80 & 0.81 & 1.61 & $0.502 \pm 0.004$ & $0.074 \pm 0.008$ & Large & metacentric \\
3 & 0.70 & 0.72 & 1.42 & $0.504 \pm 0.005$ & $0.065 \pm 0.005$ & Large & metacentric \\
$4^{*}$ & 0.61 & 0.63 & 1.24 & $0.505 \pm 0.009$ & $0.056 \pm 0.005$ & Large & metacentric \\
5 & 0.52 & 0.53 & 1.05 & $0.504 \pm 0.007$ & $0.049 \pm 0.005$ & Medium & metacentric \\
6 & 0.47 & 0.48 & 0.95 & $0.502 \pm 0.004$ & $0.043 \pm 0.005$ & Medium & submetacentric \\
7 & 0.55 & 0.98 & 1.53 & $0.636 \pm 0.025$ & $0.070 \pm 0.007$ & Large & submetacentric \\
8 & 0.48 & 0.87 & 1.35 & $0.641 \pm 0.030$ & $0.062 \pm 0.006$ & Large & submetacentric \\
9 & 0.43 & 0.76 & 1.19 & $0.635 \pm 0.034$ & $0.054 \pm 0.004$ & Large & submetacentric \\
10 & 0.37 & 0.68 & 1.05 & $0.642 \pm 0.038$ & $0.048 \pm 0.006$ & Medium & submetacentric \\
11 & 0.34 & 0.62 & 0.96 & $0.645 \pm 0.054$ & $0.043 \pm 0.005$ & Medium & acrocentric \\
12 & 0.34 & 0.99 & 1.33 & $0.744 \pm 0.029$ & $0.061 \pm 0.007$ & Large & acrocentric \\
13 & 0.29 & 0.83 & 1.12 & $0.739 \pm 0.038$ & $0.051 \pm 0.004$ & Large & acrocentric \\
14 & 0.26 & 0.75 & 1.01 & $0.741 \pm 0.034$ & $0.046 \pm 0.004$ & Medium & acrocentric \\
15 & 0.24 & 0.70 & 0.94 & $0.745 \pm 0.044$ & $0.042 \pm 0.003$ & Medium & acrocentric \\
16 & 0.21 & 0.65 & 0.86 & $0.759 \pm 0.052$ & $0.038 \pm 0.003$ & Small & acrocentric \\
17 & 0.17 & 0.58 & 0.75 & $0.773 \pm 0.047$ & $0.033 \pm 0.004$ & Small & telocentric \\
18 & 0.00 & 0.67 & 0.67 & $1.000 \pm 0.000$ & $0.030 \pm 0.006$ & Small & telocentric \\
19 & 0.00 & 0.58 & 0.58 & $1.000 \pm 0.000$ & $0.025 \pm 0.006$ & Small & telocentric \\
20 & 0.00 & 0.45 & 0.45 & $1.000 \pm 0.000$ & $0.020 \pm 0.004$ & Small & \\
\hline
\end{tabular}

Note: $*=$ NOR-bearing chromosome 


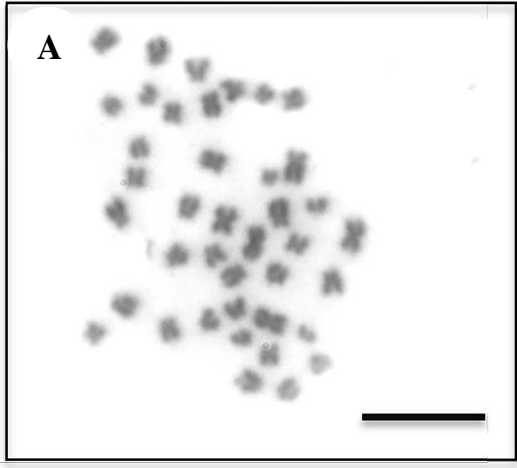

\begin{tabular}{|c|c|c|c|c|c|}
\hline 88 & 8E & 를 & $\mathbf{8}$ & $\mathbf{x}$ & $\mathbf{a}$ \\
\hline 1 & 2 & 3 & 4 & 5 & 6 \\
\hline 를 & a & $\boldsymbol{B}$ & $\boldsymbol{B}$ & $\mathbf{s}$ & \\
\hline 7 & 8 & 9 & 10 & 11 & \\
\hline $\mathbf{t}$ & 86 & a & 68 & $\mathbf{a}$ & $6 \mathbf{a}$ \\
\hline 12 & 13 & 14 & 15 & 16 & 17 \\
\hline ab & te & 를 & & & \\
\hline 18 & 19 & 20 & & & \\
\hline
\end{tabular}
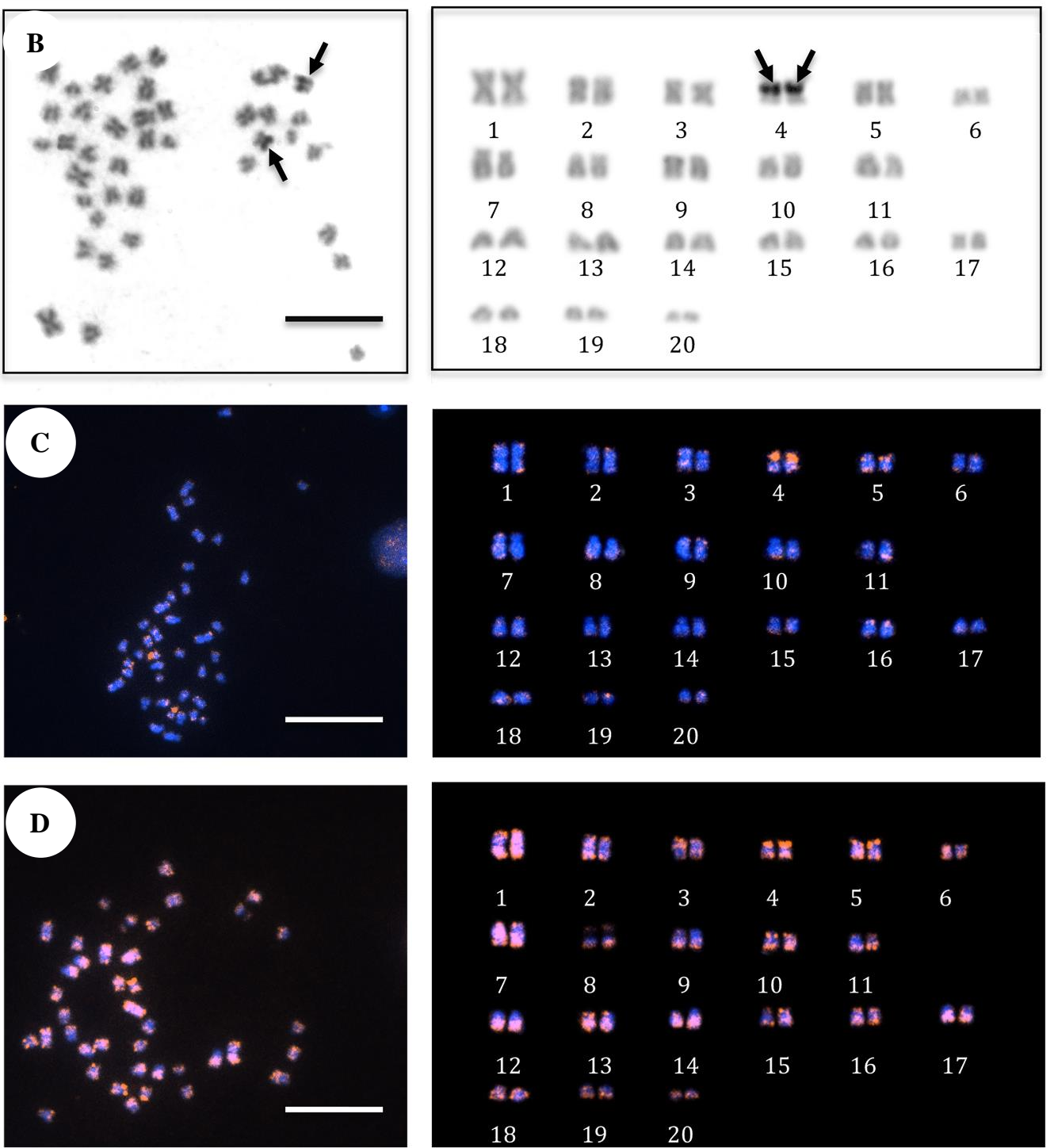

Figure 2. Metaphases and karyotypes of the pufferfish, Pao cochinchinensis, $2 n=40$ by conventional straining technique (A), Ag-NOR banding technique (B), FISH with d(CA) 15 probe (C) and FISH with $\mathrm{d}(\mathrm{CGG})_{10}$ probe (D). The arrows indicate the nucleolar organizer regions/NORs of the $4^{\text {th }}$ chromosome pair and scale bars indicate $5 \mu \mathrm{m}$ 
$\mathbf{A}$

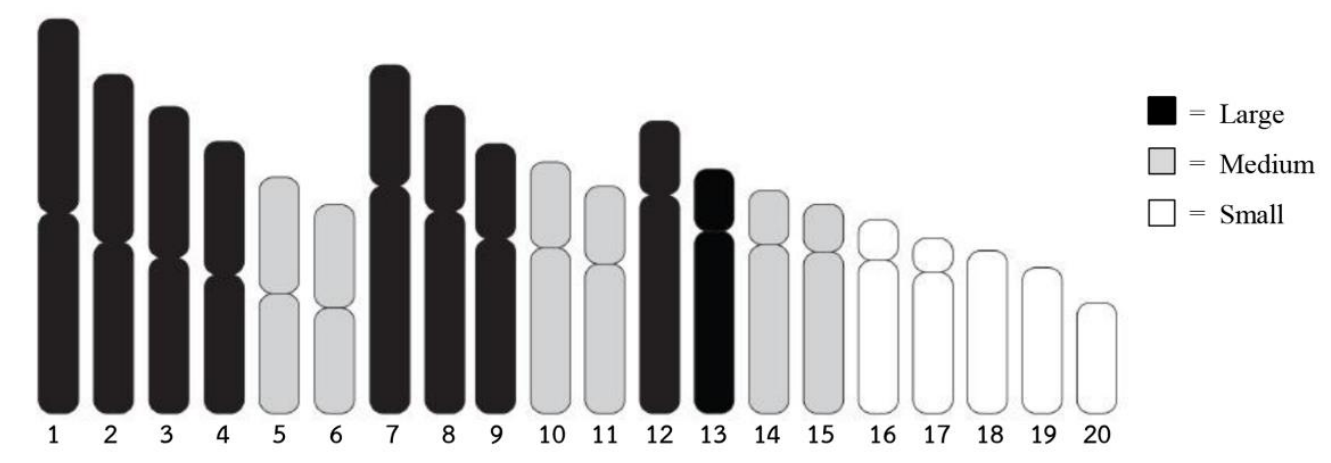

B
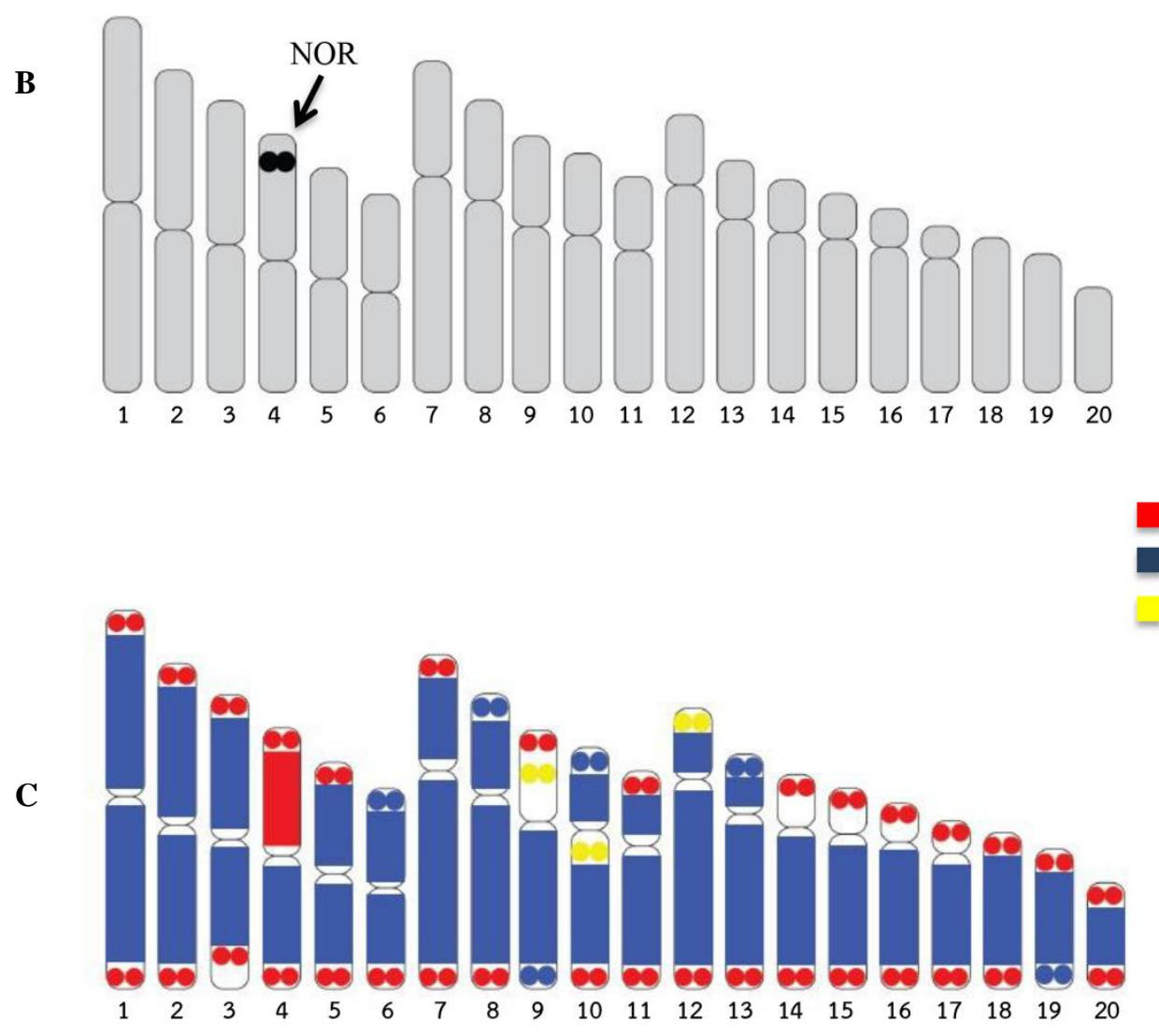

Figure 3. Idiograms showing lengths and shapes of chromosomes of the pufferfish, Pao cochinchinensis, $2 n=40$ by conventional staining technique (A), Ag-NOR banding technique (B) and FISH technique (C). Arrow indicates nucleolar organizer regions/NORs.

\section{Discussion}

Present study is the first report on karyotyping of $P$. cochinchinensis. To compare with other species in the family Tetraodontidae, the obtained result exhibited the same $2 n$ as in Canthigaster patoca (Arai 2011). However, it is different from $P$. palemnangensis (same genus) which had the $2 n$ as 42 chromosomes (Arai 2011). Moreover, they are different in $2 n$ to other pufferfish species, as shown in Table 1 ; the most frequently observed $2 n$ in this family is 42 chromosomes $(30.77 \%)$. Interestingly also NF and karyotype structure were different in all previously studied species: NFs in family Tetraodontidae vary from 36 to 74 and most species in this family have karyotypes consisting of metacentric, submetacentric, acrocentric/subtelocentric chromosomes (Table 1). Accordingly, this fish family displays a high diversity of chromosomes and karyotypes. An idiogram from conventional staining is shown in Figure 3.A. The largest chromosome of $P$. cochinchinensis has about four folds of the size of its smallest.

Chromosomal studies on fishes have been providing new information about karyotypic variability at inter- and intraspecific levels, which can be of great interest to phylogenetic, systematics, and taxonomy (Supiwong et al. 2012b). The single NOR-bearing chromosomes in the 
present result are most likely homologous to that observed in Sphoeroides greeleyi (Brum et al. 1995) and $S$. testudineus (Sá-Gabriel and Molina 2005). A single NORbearing chromosome is a common characteristic found in many fish groups as well as vertebrates (Supiwong et al. 2010, 2012a,b, 2013b, 2015, 2017, Chooseangjaew et al. 2017, Getlekha et al. 2017; Kasiroek et al. 2017; Phimphan et al. 2017; Sangpakdee et al. 2017; Chaiyasan et al. 2018). NOR mapping is frequently used to compare variations, as well as to identify and explain speciation. However, changes in chromosome number and structure can alter the number, and structure of NOR. Structure, number, and morphology of a NOR may be specific to populations, species, and subspecies. Robertsonian translocations (centric fusion) may cause losses of NORs. Species, which have limited gene exchange due to geographical isolation, have elevated karyotype numbers and NOR variation. The use of NORs in explaining kinships depends on a large extent on the uniformity of this characteristic and on the degree of variety within a taxon (Supiwong et al. 2012b).

In this study microsatellite distributions on chromosomes within the Family Tetraodontidae is done for the first time. Comparisons with other families revealed that the $d(C A)_{15}$ microsatellite repeats mapping are similar to the nine species of the Bagridae family including Hemibagrus filamentus, $H$. spilopterus, $H$. wyckii, $H$. wyckioides, Mystus atrifasciatus, M. multiradiatus, M. mysticetus, M. bocourti, and Pseudomystus siamensis (Supiwong et al. 2013a, 2014b), Clarias batrachus and $C$. macrocephalus (Maneechot et al. 2016), Toxotes chatareus (Supiwong et al. 2017). This pattern can be found in nonThai fish species. For example, the catfishes Imparfinis schubarti (Heptapteridae), Steindachneridion scripta (Pimilodidae), and Rineloricaria latirostris (Loricariidae) present a remarkable accumulation of both $\mathrm{d}(\mathrm{GA})_{15}$ and $\mathrm{d}(\mathrm{A})_{30}$ microsatellites in telomeric regions (Cioffi et al. 2011). However, this pattern is quite different from four Channa species, i.e. Ch. lucius, Ch. micropeltes, Ch. striata and Ch. gachua (Cioffi et al. 2015), Cl. gariepinus (Maneechot et al. 2016) and two cyprinid fishes, Catlocarpio siamensis and Probarbus jullieni (Saenjundaeng et al. 2018). These fishes have the patterns of $\mathrm{d}(\mathrm{CA})_{15}$ repeats which distributed throughout the chromosome without strong accumulations in specific regions in all chromosomes.

The patterns of $\mathrm{d}(\mathrm{CGG})_{10}$ repeats in $P$. cochinchinensis are similar to Ch. lucius (Cioffi et al. 2015) but they differ from other Channa that they are distributed throughout the chromosome without high accommodations in the regions related with NOR positions. Moreover, the patterns are also different from T. chatareus (Supiwong et al. 2017) and Asian swamp eel, M. albus (Supiwong et al. 2019) and the wolf fish (Hoplias malabaricus) in which 12 different microsatellite repeats, including $\mathrm{d}(\mathrm{CA})_{15}, \mathrm{~d}(\mathrm{GA})_{15}$, $\mathrm{d}(\mathrm{CAA})_{10}$, and $\mathrm{d}(\mathrm{CGG})_{10}$ repeats showed strong hybridization signals at subtelomeric and heterochromatic regions of several autosomes, with a varied amount of signal on the sex chromosomes (Cioffi et al. 2011). From the previous studies, it is believed that microsatellites have specific zones as heterochromatin (telomeres, centromeres, and in the sex chromosomes) of fish genomes (Cioffi and Bertollo 2012). However, microsatellites have also been found in noncentromeric regions, many of them were located either near or within genes (Rao et al. 2010). This phenomenon is also valid for $P$. cochinchinensis in the present study.

The first cytogenetics study in $P$. cochinchinensis, both by classical and molecular cytogenetics, led to results having the potential to contribute substantially to the understanding of chromosomal evolution in Tetraodontidae family.

\section{ACKNOWLEDGEMENTS}

This work was financially supported by the Research Capability Enhancement Program through Graduate Student Scholarship, Faculty of Science; the Post-Doctoral Training Program from Research Affairs and Graduate School )Grant no 59255(, Khon Kaen University, and Unit of Excellence 2020 on Biodiversity and Natural Resources Management, University of Phayao (UoE63005), Thailand.

\section{REFERENCES}

Alves AL, Porto-Foresti, F, Oliveira C, Foresti F. 2008. Supernumerary chromosomes in the pufferfish Sphoeroides spengleri-First occurrence in marine teleostean Tetraodontiformes fish. Genet Mol Biol 31: 243-245.

Arai R. 2011. Fish Karyotypes: A Check List. Springer, Tokyo.

Brum MJ, Oliveira CC, Galetti Jr PM. 1995. Cytogenetic studies of two puffer species )Sphoeroides, Tetraodontidae( from Rio de Janeiro Coast, Brazil. Cytologia 60: 369-374.

Brum MJI. 2000. Cytogenetic studies in tetraodontiforms Sphoeroides tyleri )Tetraodontidae( and Chilomycterus spinosus )Diodontidae( from Rio de Janeiro Coast, Brazil. Chromosome Sci 4: 103-105.

Chaiyasan P, Supiwong W, Saenjundaeng P, Seetapan K, Pinmongkhonkul S, Tanomtong A. 2018. A report on classical cytogenetics of highfin Barb fish, Cyclocheilichthys armatus (Cypriniformes, Cyprinidae). Cytologia 83 (2): 149-154.

Chooseangjaew S, Tanyaros S, Maneechot N, Buasriyot P, Getlekha N, Tanomtong A. 2017. Chromosomal characteristics of the tropical oyster, Crassostrea belcheri Sowerby, 1871 (Ostreoida, Ostreidae) by conventional and Ag-NOR banding techniques. Cytologia 82: 3-8.

Cioffi MB, Bertollo LAC, Villa MA, Oliveira EA, Tanomtong A, Yano CF, Supiwong W, Chaveerach A. 2015. Genomic organization of repetitive DNA elements and its implications for the chromosomal evolution of channid fishes (Actinopterygii, Perciformes). PLoS ONE 12: e0130199. DOI: 10.1371/journal.pone.0130199

Cioffi MB, Bertollo LAC. 2012. Distribution and evolution of repetitive DNAs in fish. In: Garrido-Ramos MA (ed.). Repetitive DNA Karger Genome Dyn 7: 197-221.

Cioffi MB, Kejnovsky E, Bertollo LAC. 2011. The chromosomal distribution of microsatellite repeats in the wolffish genome Hoplias malabaricus, focusing on the sex chromosomes. Cytogenet Genome Res 132: 289-96.

Cioffi MB, Moreira-Filho O, Ráb P, Sember A, Molina WF, Bertollo LAC. 2018. Conventional cytogenetic approaches-useful and indispensable tools in discovering fish biodiversity. Curr Genet Med Rep 6: 176-186. DOI: 10.1007/s40142-018-0148-7.

Ditcharoen S, Bertollo LAC, Ráb P, Hnátková E, Molina WF, Liehr T, Tanomtong A, Triantaphyllidis C, Ozouf-Costaz, C, Tongnunui S, Pengseng P, Supiwong W, Aroutiounian R, Cioffi MB. 2019. Genomic organization of repetitive DNA elements and extensive karyotype diversity of silurid catfishes (Teleostei: Siluriformes): A comparative cytogenetic approach. Intl J Mol Sci 20: 3545. DOI: 10.3390/ijms20143545 
Eschmeyer WN, Fricke R, Van der Laan R. 2017. Catalog of Fishes. http://researcharchive.calacademy.org/research/ichthyology/catalog/S peciesByFamily.asp

Getlekha N, Supiwong W, Pinthong K, Sriuttha M, Kasiroek W, Tanomtong A. 2017. Chromosomal characteristics of the three-spot Damselfish, Dascyllus trimaculatus (Perciformes, Pomacentridae) in Thailand. Cytologia 82 (1): 51-57.

Hardie DC, Hebert PDN. 2003. The nucleotypic effects of cellular DNA content in cartilaginous and ray-finned fishes. Genome 46: 683-706.

Hartati S, Riyah N, Yunus A, Djoar DW. 2017. Short Communication: Cytological studies on black orchid hybrid (Coelogyne pandurata Lindley). Biodiversitas 18 (2): 555-559.

Kasiroek W, Indananda C, Luangoon N, Pinthong K, Supiwong W, Tanomtong A. 2017. First chromosome analysis of the Humpback cardinalfish, Fibramia lateralis (Perciformes, Apogonidae). Cytologia 82 (1): 9-15.

Kottelat M. 2013. The fishes of the inland waters of Southeast Asia: a catalogue and core bibliography of the fishes known to occur in freshwaters, mangroves and estuaries. Raffles Bull Zool 27: 1-663.

Kubat Z, Hobza R, Vyskot B, Kejnovsky E. 2008. Microsatellite accumulation in the Y chromosome of Silene latifolia. Genome 51: 350-356.

Maneechot N, Yano CF, Bertollo LAC, Getlekha N, Molina WF, Ditcharoen S. 2016. Genomic organization of repetitive DNAs highlights chromosomal evolution in the genus Clarias )Clariidae Siluriformes(. Mol Cytogenet 9: 4.

Martinez AP, Araujo CW, Molina FW. 2010. Derived cytogenetic traits, multiple NORs and B chromosomes in the compact karyotype of Canthigaster figueiredoi )Tetraodontiformes(. Marine Genomics 3: $85-89$.

Myers P. 2008. Pufferfish and ancestral genomes. Nat Educ 1 (1): 53. http://scienceblogs.com/ pharyngula/2006/06/pufferfish and ancestral_genom.php

Phimphan S, Supiwong W, Tanomtong A, Pinthong K, Sangpakdee W, Kaewsri S. 2017. Karyotypic study of five Lutjanid species using conventional and Ag-NORs banding techniques. Cytol Genet 51 (4): 315-324.

Rao SR, Trivedi S, Emmanue D, Merita K, Hynniewta M. 2010. DNA repetitive sequences-types, distribution and function: A review. J Cell Mol Biol 7 (2) \& 8 (1): 1-11.

Saenjundaeng P, Cioffi M de B, Oliveira EA, Tanomtong A, Supiwong W, Phimphan S, Collares-Pereira MJ, Sember A, Bertollo LAC, Liehr T, Yano CF, Hatanaka T, Ráb P. 2018. Chromosomes of Asian cyprinid fishes: cytogenetic analysis of two representatives of small paleotetraploid tribe Probarbini. Mol Cytogenet 11: 51. DOI 10.1186/s13039-018-0399-8

Sá-Gabriel LG, Molina WF. 2005. Karyotype diversification in fishes of the Balistidae, Diodontidae and Tetraodontidae )Tetraodontiformes(. Caryologia 58: 229-237.

Sangpakdee W, Phimphan S, Tengjaroenkul B, Pinthong K, Neeratanaphan L, Tanomtong A. 2017. Cytogenetic study of tree microhylid species (Anura, Microhylidae) from Thailand. Cytologia 82: $67-74$.

Supiwong W, Jiwyam W, Sreeputhorn K, Maneechot N, Bertollo LAC, Cioffi MB, Getlekha N, Tanomtong A. 2017. First reports on classical and molecular cytogenetics of archerfish, Toxotes chatareus (Perciformes: Toxotidae). Nucleus 60 (3): 3493-359. DOI: 10.1007/s13237-017-0216-5.

Supiwong W, Liehr T, Cioffi MB, Chaveerach A, Kosyakova N, Fan X, Tanee T, Tanomtong A. 2014a. Comparative cytogenetic mapping of rRNA genes among naked catfishes: Implications for genomic evolution in the Bagridae family. Genet Mol Res 13 )4(: 9533-9542.

Supiwong W, Liehr T, Cioffi MB, Chaveerach A, Kosyakova N, Pinthong K, Tanee T, Tanomtong A. 2013a. Karyotype description and cytogenetic mapping of 9 classes of repetitive DNAs on the Thailand catfish Mystus bocourti. Mol Cytogenet 6: 51. DOI: 10.1186/17558166-6-51.

Supiwong W, Liehr T, Cioffi MB, Chaveerach A, Kosyakova N, Pinthong K, Tanee T, Tanomtong A. 2014b. Chromosomal evolution in naked catfishes )Bagridae, Siluriformes(. A comparative chromosome mapping study. Zool Anz 253: 316-320.

Supiwong W, Pinthong K, Seetapan K, Saenjundaeng P, Bertollo LAC, de Oliveira EA, Yano CF, Liehr T, Phimphan S, Tanomtong A, Cioffi MB. 2019. Karyotype diversity and evolutionary trends in the Asian swamp eel Monopterus albus (Synbranchiformes, Synbranchidae): a case of chromosomal speciation? BMC Evol Biol 19: 73. DOI: 10.1186/s12862-019-1393-4.

Supiwong W, Tanomtong A, Chaveerach A, Tanee T, Khakhong S, Sanoamuang L. 2013b. Interpopulational variation of NOR positions and karyotypic analysis of Siamese catfish (Pseudomystus siamensis) in Thailand. Cytologia 78 (2): 25-34.

Supiwong W, Tanomtong A, Jumrusthanasan S, Khakhong S, Leelarasamee K, Sanoamuang L. 2012a. A first karyotype analysis and chromosomal characteristic of nucleolar organizer regions (NORs) in the common sheathfish, Micronema apogon (Siluriformes, Siluridae) in Thailand. Cytologia 77 (1): 53-58.

Supiwong W, Tanomtong A, Kenthao A, Seetapan K, Kaewsri S. 2010. Standardized karyotype and ideogram of the three-spot gourami, Trichogaster trichopterus (Perciformes, Belontidae) from Thailand by conventional staining and Ag-NOR staining techniques. The Nucleus 53 (3): 103-107.

Supiwong W, Tanomtong A, Pinthong K, Kaewmad P, Poungnak P, Jangsuwan N. 2015. The first chromosomal characteristics of nucleolar organizer regions and karyological analysis of pink anemonefish, Amphiprion perideraion (Perciformes, Amphiprioninae). Cytologia 80 (3): 271-278.

Supiwong W, Tanomtong A, Supanuam P, Jantarat S, Khakhong S, Leelarasamee K, Sanoamuang L. 2012b. A discovery of nucleolar organizer regions (NORs) polymorphism and karyological analysis of Smith's barb, Puntioplites proctozysron (Cypriniformes, Cyprinidae) in Thailand. Cytologia 77 (1): 35-42.

Tanomtong A, Supiwong W, Jearranaiprepame P, Khakhong S, Kongpironchuen C, Getlekha N. 2014. A new natural autotetraploid and chromosomal characteristics of dwarf snakehead fish, Channa gachua (Perciformes, Channidae) in Thailand. Cytologia 79 (1): 15 27.

Zhou H, Fujimoto T, Adachi S, Abe S, Yamaha E. Arai K. 2013. Molecular cytogenetic study on the ploidy status in Acipenser mikadoi. J Appl Ichthyol 29: 51-55. 